NBER WORKING PAPER SERIES

\title{
AGEING-DRIVEN MIGRATION AND REDISTRIBUTION: COMPARING POLICY REGIMES
}

\author{
Assaf Razin \\ Alexander Horst Schwemmer \\ Working Paper 26998 \\ http://www.nber.org/papers/w26998 \\ NATIONAL BUREAU OF ECONOMIC RESEARCH \\ 1050 Massachusetts Avenue \\ Cambridge, MA 02138 \\ April 2020
}

The views expressed herein are those of the authors and do not necessarily reflect the views of the National Bureau of Economic Research.

NBER working papers are circulated for discussion and comment purposes. They have not been peer-reviewed or been subject to the review by the NBER Board of Directors that accompanies official NBER publications.

(C) 2020 by Assaf Razin and Alexander Horst Schwemmer. All rights reserved. Short sections of text, not to exceed two paragraphs, may be quoted without explicit permission provided that full credit, including $\odot$ notice, is given to the source. 
Ageing-Driven Migration and Redistribution: Comparing Policy Regimes Assaf Razin and Alexander Horst Schwemmer

NBER Working Paper No. 26998

April 2020

JEL No. F2,F22,H3,H4,J11

\begin{abstract}
$\underline{\text { ABSTRACT }}$
Life cycle and insurance-type considerations dominate redistribution policy. Wage and fiscal prospects of ageing dominate migration policy. The paper compares distinct policy regimes, directed at migration and redistribution issues. Migration quotas, provision of social benefits, labor income taxation, and capital income taxation, are all endogenously determined in a policyoptimizing framework. The analysis makes a three-way comparison: free-migration regime vs. restricted-migration regime, welfare-state regime vs. no-migration-quota, no-redistribution regime, and low-income-majority regime vs. high-income-majority regime.
\end{abstract}

Assaf Razin

Eitan Berglas School of Economics

Tel Aviv University

Tel Aviv 69978

ISRAEL

and Cornell University and CEPR

and also NBER

razin@tauex.tau.ac.il

Alexander Horst Schwemmer

Department of Economics

Ludwig-Maximilians-Universität

Geschwister-Scholl-Platz

Munich, 80539

Germany

alexander.schwemmer@ outlook.com 


\begin{abstract}
Life cycle and insurance-type considerations dominate redistribution policy. Wage and fiscal prospects of ageing dominate migration policy. The paper compares distinct policy regimes, directed at migration and redistribution issues. Migration quotas, provision of social benefits, labor income taxation, and capital income taxation, are all endogenously determined in a policy-optimizing framework. The analysis makes a three-way comparison: free-migration regime vs. restricted-migration regime, welfare-state regime vs. nomigration-quota, no-redistribution regime, and low-income-majority regime vs. high-income-majority regime.
\end{abstract}

\title{
I. Introduction
}

The developed world in the last few decades has experience an unprecedented demographic change. In virtually all OECD countries, people are getting older - a lot older. The reasons are dramatic baby bust, following the equally dramatic baby boom, and the remarkable increase in life expectancy. Fiscal prospects depend on two factors, in order to mitigate adverse macroeconomic impact of ageing. The first is the potential for capital deepening. The second is increased immigration. 
The potential for a big surge in cross-border labor mobility is beyond that has ever been before. ${ }^{1}$

First, gaps between what the same worker can make in one country versus another are higher than they have ever been in history. That is, gaps are much higher than the wage differentials that drove the "mass migration" at the nineteenth century and early $20^{\text {th }}$ century. Second, ageing trends in the migrationdestination countries decrease the supply of young workers in them. Third, the globalization of finance, information, and trade, lessen costs of international labor mobility. However, the main hurdle to labor mobility are restriction on immigration by the host countries. The potential for massive migration could only come about if administrative migration barriers were to be lifted. That is, as with the "mass migration" in the nineteenth century migration becomes free. ${ }^{2}$

One reason for migration restrictions emerges from the negative effect of immigration on native-born employment and wages. ${ }^{3}$ Another reason for the rise of policy-based restrictions on cross-border migration is the advent of a more generous welfare state. ${ }^{4}$ Milton Friedman famously quipped: "free

\footnotetext{
${ }^{1}$ See Prichett (2006) insightful essay.
}

${ }^{2}$ Between 1850 and 1915, during the Age of Mass Migration, the US attracted close to 30 million European immigrants, and the foreign-born share of the US population peaked at $14 \%$ (Abramitzky and Boustan (2017)).

${ }^{3}$ See the findings in Borjas (2003) and Dustmann et al. (2017) among others, it is in contrast with results in Card (2001, 2005), Foged and Peri (2016), and Ottaviano and Peri (2012), who document that immigrants have a negligible, or even positive, impact on native-born earnings.

${ }^{4}$ During the Age of Mass Migration, more than 30 million people moved from Europe to the US (Abramitzky and Boustan (2017)), and the share of immigrants in the US population was even higher than it is today. During the 1910s and the 1920s the US pattern of voters radically changed (e.g., women received voting rights) and a welfare state institutions started to emerge. 
immigration and a welfare state are incompatible". ${ }^{5}$ However, as population ageing progresses, and the share of native born which depend on the provision of social benefits rises, the welfare state benefits from unrestricted migration. It needs more immigrants for the sustainability of the social insurance system. $^{6}$

Commodity prices vary across countries due to several reasons: different tax rates, market segmentation, different standards, transportation costs, etc. However, the forces of free trade tend to narrow these differences. These forces are enhanced by multi-lateral trade agreements reached under the auspices of the World Trade Organization (WTO); by regional trade agreements, such as the North America Free Trade Agreement (NAFTA); or by other bilateral trade agreements, such as the one between Switzerland and the European Union (the EU), and the one between Norway and the EU. In contrast, wages of individuals with similar labor- market traits differ considerably across countries, especially between advanced and developing countries. Such high differences cannot persist under free migration;. They exist mostly because sovereign states restrict migration. Among such states, there is no

Anti-immigration sentiments were widespread, and the introduction of immigration restrictions is advocated on both economic and cultural grounds.

${ }^{5}$ Israel provides a counter example. The constitutional Law of Return imposes no immigration barriers two the Jewish diaspora (see Razin (2018)). Israel, which has a modern welfare-state system, not only enables free immigration but also grants Jewish immigrants immediate citizenship, regardless of origin or skill. The EU is another modern counter example to his observation. Every EU country is obligated to enable free entrance to any individual originated in other EU country, while each country retains its own welfare-state system.

${ }^{6}$ See Zaicheva and Zimmermann (2016) for a recent literature survey of population ageing and international migration. 
WTO-like organization such as the WTO which can coordinate sustainable reductions in the administrative barriers to migration.

Restrictions on the international mobility of labor are arguably the single largest policy distortion that besets the international economy. A variety of studies suggests that even a small reduction in barriers to migration will result in large welfare benefits to the global economy. Unlike international trade in goods, or

international financial flows, migration can change the decision -making policy in the an economy. This is because population composition in terms of income, age, etc., can alter the power balance between the native-born and the newcomers in a way that changes the political-economic policy of the state. Nevertheless, despite the potential gains from easing restrictions on international labor mobility, countries do not pursue the liberalization of migration flows unilaterally, or through negotiations, in a way that international trade negotiations do. 2 Why is this? Because politicians face a backlash against immigration. Among several key explanations for this, is the fiscal burden imposed by immigration on the native-born.

Lindbeck (1985) observes that during the first part of the 20th century, life cycle and insurance-type considerations seem to have dominated redistribution policy. By contrast, during the decades following WWII, 'fragmented horizontal redistributions' between various minority groups have probably been the most important mechanisms. The self-interest of different groups of the electorate seems to have provided the most powerful motive behind redistribution in favor of the poor.

A representative welfare state, with its relatively abundant supply of capital, and high productivity (implying relatively high wages for all skill levels) is able to attract both unskilled-poor and skilled-rich migrants. However, its relative generosity attract relatively more unskilled-poor migrants. They expect to gain more 
from the benefits of the welfare state than what they pay in taxes. A note-worthy trend in migration policy in the OECD countries is the move toward restricting migration, by placing more emphasis on skills. ${ }^{7}$ That is, immigrants with high skills and education are preferred over immigrants with low skills and education. Skillselection immigration policy has been instituted in Australia, New Zealand and Canada. The US also adopted such rules in 1990, as have a growing number of EU countries, including France, Ireland and the UK ${ }^{8}$. Major immigrant-receiving countries increasingly are examining how to select immigrants across a range of skill levels, retain those with the greatest potential to succeed, engage employers constructively in the immigration process.

Welfare-state voters are motivated in their voting preferences not only on how migration affects their wage income. That is, since the welfare state redistributes income from the rich to the poor, unskilled migrants, over lifetime, are net beneficiaries of the welfare state. In contrast, skilled (rich) migrants are in general net contributors. Consequently, a under free migration, the migrant skill composition is tilted towards the unskilled; whereas under controlled migration regime, the skill composition is skewed towards the skilled.

\footnotetext{
${ }^{7}$ This trend is documented in Kapur and McHalet (2005), ${ }^{8} \mathrm{~A}$ point-based system is a method to rank applications for residence and work permits. It has been adopted by Australia, Canada, and New Zealand and, in Europe, by Switzerland. In such a system, each application is allocated a score based on explicit criteria which typically reward educational attainment, experience, and language abilities. "Bonus points" can also be given for employment in occupations and regions where there is a shortage of workers. Recently, the UK proposed a new system, billed as a "points-based system", which treats migrants equally, regardless of where they come from. After Brexit, Europeans will no longer benefit from freedom of movement. Policy preferred occupations are "shortage occupation list" (SOL), central to the government's planned new immigration rules. Most immigrants will need to speak English and have a job offer with a prospective salary of more than $£ 25,600(\$ 33,245)$.
} 
However, voters are driven also by how migration bears on the social insurance system, when they retire, become unemployed, etc. Migration effects on the social insurance system are common to voter preferences, regardless of skills. From the public-finance point of view, native-born voters opt for high- skilled migrants to come on shore; whereas, for the unskilled to stay away, to mitigate the fiscal burden on them. Therefore, notwithstanding the common interests in social insurance, the different income effects of migration on voters, every welfare state unavoidably adopts migration regulations and restrictions ${ }^{9}$.

The purpose of this paper is compare different social insurance and migration policy regimes by using a stylized international-macroeconomic framework. Key policy variables are the provision of social benefits, determined jointly with skill-based migration policy. tax policies, capital mobility, good mobility, and policy, are all endogenously being determined in a general-equilibrium setup. Features analyzed are self-interest income group, ageing, and globalization. To this end, we develop a model in which (life-cycle) social insurance and skill-based migration policies, are driven by the ageing of the population. Our analysis involves a three-way comparison: free-migration regime contrasted with a controlled-migration regime, welfare-state regime contrasted with free-market regime, and skilledrich controlled regime vs. unskilled-poor controlled regime.

The paper is organized as follows. Section II briefs on relevant literature. Section III describes the main blocks of the model. Section IV presents model predictions, based on simulation results, and Section V concludes.

\section{Literature}

Gary Freeman (1986) observes, “The logic of the welfare state implies the existence of boundaries that distinguish those who are members of the community from those who are not.

\footnotetext{
${ }^{9}$ See Razin et al. (2011).
} 
Migration continuously intrude on, and challenge, the endogenous nature of the welfare state.” At the same time redistribution policies by the welfare state, through inherent political-economic forces set strict limits to the free mobility of people. All industrial countries, which are the major host countries for migration, uphold extensive welfare state systems. They provide some combination of income support and direct provision of goods (e.g., housing, health care, education).

As for migration, the standard theory concludes that the major cause is wage-level differences among countries. Labor migration would stop if wage differences vanish. ${ }^{10}$ However, the generosity of the welfare state should also be included as a trigger. When it comes to the interaction of migration policy and the welfare-state-generosity policy, one argument often heard in public debate is the view that immigrants are drawn towards a more generous welfare systems of the receiving countries. This is the basis for welfare-state-as-magnet hypothesis. However a fundamental question that remains unanswered is how migration policy is determined in the first place. Is it originates from the source country preferences of would be migrants; is it restricted by policy maker preferences in the destination country; or whether migration is determined by both forces. The former driving force, that migration is determined at the source, and workers entering the "open doors to heaven" has been the tradition in the labor economics literature (Borjas (1999)). In reality, who is allowed into a country, depends on active immigration policy of receiving countries; not the source countries. Receiving countries

\footnotetext{
10 This theory suggests that the labor migration moves from capital-poor/labor force-rich countries to capital-rich/labor force-poor countries, while by contrast capital moves in the opposite direction, expecting a higher return on investment made in capital-poor countries.
} 
more often than not enact quotas, point systems, and the like, in order to select those immigrants whom they deem most desirable (see Razin et al (2002). ${ }^{11}$ Models in which redistribution policy is determined by the majority rule predicts that the median voter serves as a major check on inequality via redistributive policies. ${ }^{12}$

High and lasting restrictions on immigration stand in marked contrast to accelerating liberalization of the goods markets, starting soon after World War II through the GATT, and liberalization of capital markets starting after the breakdown of the Bretton woods system in 1973. At present, markets for goods and services as well as capital are global, whereas labor markets are still national, without much policy to liberalize immigration; see Freeman (2006). Economic historian KhoudourCastéras (2008) studies migration from the 19th century Europe. He finds that the social insurance legislation, adopted by Bismarck in the 1880s, reduced the incentives of risk averse Germans to emigrate. He estimates that in the absence of social insurance, German emigration rate from 1886 to 1913 would have been more than doubled their actual level. Southwick (1981) shows with US data that high welfare-state benefit gap, between the origin and destination regions in the US, increases the share the welfare-state benefit recipients among the migrants. Gramlich and Laren (1984)

\footnotetext{
${ }^{11}$ Facchini, Razin, and Willman (2004) extend their analysis to investigate the role of lobbying in shaping migration policy.
}

12 Traditional theory of the determinants of the size of the government in a direct democracy highlights the relationship between the scope of redistribution, i.e. the extent of the welfare state, and pre-tax income inequality. Two interpretations explain this dependence: Lovell (1975) emphasize the size of the government as a provider of public goods, while others such as in the traditional median voter models of redistribution in Roberts (1997), Meltzer, and Richard (1981). They emphasize the role of extensions of the voting franchise and the pre- tax inequality on redistribution of income. 
analyze a sample from the 1980 US Census data and find that the high-benefit regions will have more welfare-recipient migrants than the low-benefit regions. Using the same data, Blank (1988) employs a multinomial logit model to show that welfare benefits have a significant positive effect over the location choice of female-headed households. Meyer (2003) employs a conditional logit model, as well as a comparison-group method, to analyze the 1980 and 1990 US Census data and finds significant welfare-induced migration, particularly for high school dropouts. Borjas (1999), who uses the same data set, finds that low-skilled migrants are much more heavily clustered in high-benefit states, in comparison to other migrants or natives. Gelbach (2004) finds strong evidence of welfare migration in 1980, but less in 1990. Levine and Zimmerman (1999) estimate a probit model using a data set for the period 1979-1992 and find, on the contrary, that welfare benefits have little effect on the probability of female-headed households (the recipients of the benefits) to relocate. Dustmann and Frattini (2014) bring evidence of no welfare migration.

Razin and Wahba (2014) decompose bi-lateral migration sample into three groups as follows. Group A (EUR to EUR) contains only the source-host pairs of countries, which allow free mobility of labor between them, according to the Schengen agreement. Razin and Wahba (2014) find that a more generous welfare state tilts the skill composition downward under free migration and upward under policy- controlled migration. Regardless whether migration is free or controlled a higher Gini generates greater income distribution and consequently more skill-biased immigration In Razin, Sadka and Swagel (2002) the dependency effect of unskilled migrants on the welfare-state policy depends on two contrasting driving forces. On the one hand, the effect is negative because a rise in the dependency ratio increases the fiscal burden on the median voter. On the other hand, the dependency-ratio effect on policy is positive to the extent that the median voter preference shifts towards the group of voters who are net beneficiary of the welfare state. In the present context of 
two skill levels, the effects of a rise in the dependency ratio on the welfare-state generosity policy is negative if the high skill are in the majority, and positive if the low skill are in the majority13.

Notwithstanding the great insights arising from the above-mentioned literature, complex interactions among the driving forces are to be further explained in only a general equilibrium framework. The paper addresses the general-equilibrium interactions in a majority-voting analytical framework.

\section{Minimalist Model}

We develop a two-period political-economy model, capturing skill based immigration policy jointly and welfare-state redistribution policy, that are determined through majority voting ${ }^{14}$. The

13 Interest-group arguments in political science date back more than a century. From the pioneering works of Arthur F. Bentley (1908), V.O. Key, Jr. (1942) to David B. Truman (1951). Group models of politics search for propositions about how and when individuals coordinate their activities and engage in collective behavior (Olson 1971). Work in this vein commonly attempts to link policy demands to concrete (or expected) gains and losses of identifiable sub-groups of the electorate, and to the bargains and concessions, they produce in pluralistic political systems. Interest-group approaches have focused on a broad array of groups positioned for or against immigration (Freeman 1995; Gimpel and Edwards 1999; Haus 1995; Joppke 1998; Watts 2001).

${ }^{14}$ The model draws on Razin et al (2019). The framework consists of two skill levels in a Heckscher-Ohlin setting where factors of production are perfectly mobile across sectors. Using public opinion polls conducted in the United States, Steve and Slaughter (2001) and O'Rourke (2003), find support for hypotheses derived from the HeckscherOhlin trade model. Specifically, they find that there is a robust skills cleavage over immigration policy, with highly skilled workers being less likely to support restricting immigration policies and lowskilled counterparts more likely to do so; and these effects of immigration on workers at different skill levels are consistent with the model. Their findings suggest 'the potential for immigration 
government provides a uniform social benefit. Capital income tax is proportional whereas the average rate of the labor income tax progresses from low-skilled wage to high-skilled wage.

\section{III.1 Income groups}

In order to consider redistribution issues, which are at the heart of the welfare state, we assume that there minimally are two types of individuals -- low skilled-poor (indexed $u$ ) and high skilled -rich (indexed $s$ ). The workers have two types of skills-low (l) and high (h). There are three types of factors of production—capital $(\mathrm{K})$ high-skilled labor $\left(L_{H}\right)$, and low-skilled labor $\left(L_{H}\right) .{ }^{15}$

Each high-skill individual is endowed with $\bar{x}_{s}$ units of good x, and $\bar{y}_{s}$ units of good y, respectively, in the first period; a low-skill individual is endowed with only $\theta<1$ units of a skilled individual's wealth endowment. Thus, a skilled-rich individual enjoys both higher initial endowment (“wealth”), and higher labor market skill than the unskilled-poor individual.

Ageing leads to increasing dependency ratio - the ratio of retirees to workers- is the main driving force in our analysis.

politics to be connected to the mainstream redistributive politics over which political parties often contest elections.

15 When confining consideration to factor rewards, under the standard complementaritysubstitution specification of production functions, low skill labor, and capital, benefit from high skill immigration, whereas high skill labor loses. However, such narrow benefit-lose calculation abstracts from the general-equilibrium effect factor allocation across sectors, international capital flows and from the fiscal aspects associated with the welfare state. 
To capture the essence of ageing, we assume an idiosyncratic shock in the second period so that, with certain likelihood the individual retires from work.

The overall size of the initial native-born population is normalized to one, where a proportion $\lambda$ of the population is of high skill and a proportion $1-\lambda$ is of low skill. We denote by $m_{s}$ the number of high-skill migrants and by $m_{l}$ the number of low-skill migrants. We denote the number of highskill immigrants, $m_{S}$, and low-skill immigrants, $m_{L}$.

\section{III.2 Dependents}

The welfare state provides universal social benefits, paid by tax on labor income and tax on capital income. There are two periods. We assume that everyone works in the first period. As for the second period, with a probability $\emptyset$, an individual is out of work, earning no wage income. The individual draws on the earned income which is saved from the first period. We label this individual as dependent, because relative to others in the same skill group, the individual spending draws more the welfare-state social transfers. To capture dependency on the social insurance through retirement, unemployment, disability, etc., we assume that there is an individual idiosyncratic shock. The probability of non-work realization is also the share of dependents in the population. Because migrants typically come in young and productive, the non-working shock does not apply to them.

\section{III.3 Immigration}

Immigrants, who bring with them no capital, consume only in the second period, and their utility function is given by:

$u=\left(c_{x 2}\right)^{\alpha}\left(c_{y 2}\right)^{1-\alpha}+d B^{\gamma}$ 
Consumption functions are:

(1a) $\quad c_{x m S 2}=a\left(1-t_{L S}\right)\left(w_{H}\right)$

and

$$
c_{y m S 2}=(1-a)\left(1-t_{L S}\right)\left(w_{H} / \mathrm{p}\right)
$$

(1c) $\quad c_{x m L 2}=a(1-b)\left(1-t_{L L}\right)\left(w_{L}\right)$

and

$$
c_{y m L 2}=(1-a)(1-b)\left(1-t_{L L}\right)\left(w_{L} / \mathrm{p}\right)
$$

Where $t_{L S}$ and $t_{L L}$ denote wage proportional wage tax rates on high-skill and low-skill, respectively.

The exogenously given pair $u_{H}^{*}, u_{L}^{*}$ of utility levels attained by S-individuals and L-individuals, respectively, in foreign residence. The number of high skilled immigrants depends positively on the foreigndomestic utility differential, $u_{s m}-u_{S}^{*}$; and number of low skilled immigrants depends positively on the foreign-domestic utility differential $u_{L m}-u_{L}^{*}$. 
Under the free migration regime, the number of migrants are determined as follows.

$$
\begin{gathered}
m_{H}=Z_{H}\left(u_{m H}-u_{H}^{*}\right)^{z_{H}} \quad \text { with } Z_{H}>0,0<z_{H}<1 . \\
m_{L}=Z_{L}\left(u_{L m}-u_{L}^{*}\right)^{z_{L}} \quad \text { with } Z_{L}>0,0<z_{L}<1 .
\end{gathered}
$$

For consistency, under a controlled-migration regime, $m_{H}$ and $m_{L}$ are policy controlled variables. The migration quotas must be chosen so that

$$
u_{m H}-u_{H}^{*}<\left(\frac{m_{H}}{z_{H}}\right)^{-z_{H}} \text {, and } u_{m L}-u_{L}^{*}<\left(\frac{m_{L}}{z_{L}}\right)^{-z_{L}} \text {. }
$$

\section{III.4 Production and investment}

To enable us to consider trade in goods we assume that there minimally are two tradable goods ( $\mathrm{x}$ and y). In the absence of uncertainty and differentiated products, each sector will either export or import its standard product, but not both at the same time. World prices of $\mathrm{x}$ and $\mathrm{y}$ are exogenously given for our small open economy with good x serving as a numeraire, whose price is normalized to one, and the world price of $\mathrm{y}$ is denoted by $\mathrm{p}^{*}$. There is an impediment to trade in goods. Specifically, goods can be exported, but again only at some border related friction cost (e.g., country specific standards, regulations, etc.). For concreteness of the notation, we consider y as an 
export good. A similar and straightforward notation applies when $\mathrm{x}$ is the export good. ${ }^{16}$ We denote this cost per unit of price by $\delta_{y}$, so that the domestic price of the export good y is

$$
p_{t}=\frac{p^{*}}{\left(1+\delta_{y}\right)}
$$

A representative firm produces well $g$ according to a constant-returns-to scale technology:

$$
g=A_{g} F_{g}\left(K_{g}, L_{H g}, L_{H g}\right)=A_{g} K_{g}^{\alpha_{g}} L_{H g}^{\rho_{g}} L_{L g}^{1-\rho_{g-\alpha_{g}}}, \quad g=x, y,
$$

Where, $K_{\mathrm{g}}$ is the input of physical capital, and $L_{H g}$ is high-skill labor, and $L_{L g}$ is low-skill labor, used in the respective production process. $A_{g}>0$ Is a total factor productivity coefficient, and $\alpha_{g}, \rho_{g}$, and $1-\rho_{g}-\alpha_{g}$ are, respectively, the capital, high-skill labor, and low-skill labor shares in the sector producing $g$.

Capital is employed together with labor in the first period with output generated in the second period. We assume that labor is paid in the second period, at the end of the production process.

Capital $(K)$ is a composite good, produced in the first period is of a variable mix of $x_{k}$ and $y_{k}$, according to:

$$
K=x_{k}^{\beta} y_{k}^{1-\beta} \text {, where } 0<\beta<1 \text {. }
$$

\footnotetext{
${ }^{16}$ By the Lerner Symmetry proposition, any wedge between the domestic and the world prices applied to importable goods, is equivalent to a wedge between world and domestic prices applied to exportable goods.
} 
To find the cost minimizing mix of $\mathrm{x}$ and $\mathrm{y}$, of which a unit of capital $(\mathrm{K})$ is composed of, one, has to solve the following problem:

$$
\min _{(x, y)}\left(x_{k}+p_{1} y_{k}\right)
$$

Subject to:

$$
x_{k}^{\beta} y_{k}^{1-\beta} \geq 1,
$$

Where $p_{t}$ is the domestic price of $y$ in period $t=1,2$.

Solving this problem yields also the unit price $p_{k}$ of capital as

(7) $\quad p_{k}=D p_{1}^{1-\beta}$,

where $D=\left(\frac{1-\beta}{\beta}\right)^{\beta}+\left(\frac{\beta}{1-\beta}\right)^{1-\beta}$.

Demands for labor and capital are given, respectively, by the marginal productivity conditions in both sectors. Note that because labor and capital move freely between the two sectors, then the factors of production earn the same remuneration across sectors, that is:

$$
w_{H}=\left(\rho_{x}\right) A_{x} k_{H x}^{\alpha_{x}} l_{L x}^{1-\rho_{x-} \alpha_{x}},
$$

$$
w_{H}=p_{2}\left(\rho_{y}\right) A_{y} k_{H y}^{\alpha_{y}} l_{L y}^{1-\rho_{y-} \alpha_{y}}
$$




$$
\begin{aligned}
& w_{L}=\left(1-\alpha_{x}-\rho_{x}\right) A_{x} k_{H x}^{\alpha_{x}} l_{L x}^{-\rho_{x-} \alpha_{x}} \\
& w_{L}=\left(1-\alpha_{y}-\rho_{y}\right) A_{y} k_{H y}^{\alpha_{y}} l_{L y}^{-\rho_{y-} \alpha_{y}}
\end{aligned}
$$

$$
\begin{aligned}
& p_{k}(1+r)=\alpha_{x} A_{x} k_{H x}^{\alpha_{x}-1} l_{L x}^{1-\rho_{x-} \alpha_{x}}, \\
& p_{k}(1+r)=\quad p_{2} \alpha_{y} A_{y} k_{H y}^{\alpha_{y}-1} l_{L y}^{1-\rho_{y-} \alpha_{y}},
\end{aligned}
$$

Where $k_{g}$ is the capital- labor ratio in sector $g$, that is $k_{H g}=\frac{K_{g}}{L_{H g}} ; l_{L g}=\frac{L_{L g}}{L_{H g}} ; w_{H}$ is high-skill wage rate, paid in the second period (after the completion of the production process); and $w_{L}$ is low-skill wage rate, paid in the second period after the completion of the production process. Note that for simplicity we assume that capital fully depreciates at the end of the production process.

\section{III.5 Saving behavior}

We denote by $c_{g i 1}$ the consumption of good $\mathrm{g}=\mathrm{x}$, $\mathrm{y}$ by an individual of type $\mathrm{i}=\mathrm{u}, \mathrm{s}$ in period $\mathrm{t}=$ 1,2. All native-born individuals have identical preferences, given by

$$
u_{i}=\left(c_{x i 1}{ }^{a} c_{y i 1}{ }^{1-a}\right)^{b}\left(c_{x i 2}{ }^{a} c_{y i 2}{ }^{1-a}\right)^{1-b}+d B^{\gamma},
$$


Where, $0<\mathrm{a}<1,0<\mathrm{b}<1, \mathrm{~d}>0, \gamma>0$, and $B$ is a uniform social benefit (provided in an equal amount to all individuals), assumed (for simplicity) to be provided in the second period only. This social benefit captures the various ingredients that a welfare state provides, such as health services, education, in-kind transfers, etc. Note that the social benefit is not a perfect substitute to private consumption $^{17}$.

The consumption basket remains the same across period 1 and 2 . Therefore, we can aggregate consumption goods into a consumption composite:

$C_{t}=C_{x t}^{a} C_{y t}^{1-a}, \mathrm{t}=1,2$

The composite price is $p_{t}=\Gamma_{p} p_{x t}^{a} p_{y t}^{1-a}$

With, $\Gamma_{P}=\frac{1}{a^{a}(1-a)^{1-a}}, \quad, \mathrm{t}=1,2$.

17 In our model, the redistribution made by the welfare state is in the form of an in-kind benefit. There are other aspects of the social insurance system that we abstract from. For example, in Europe the welfare system is more in the tradition of Beveridge (based on universal at benefits). In some non-European countries, the system is mainly Bismarkian (based on benefits related to past contributions). Since social contributions are related to individual incomes, the more Beveridgean welfare systems have a higher implicit income redistribution. See Cremer and Goulão (2014). 
The (two-state) idiosyncratic shock $\emptyset$, which occurs in the second period, is indexed $\epsilon$, where, $\epsilon=W$, if the individual works, or $\epsilon=R$, if the individual retires from work; with the probability of the nonworking state, $\emptyset$, and the probability of the working state, 1 - $\emptyset$.

The Individual household I seeks to maximize the expected utility

$$
U_{i}=C_{1 i}+\beta \mathbf{E}_{\epsilon}\left[\log C_{2 i}(\epsilon)\right]
$$

Subject to

$C_{1 i}+S_{1 i}=\bar{x}_{i}+p \bar{y}_{i}$, and

$$
\begin{gathered}
S_{i}\left[1+\left(1-t_{k}\right) r\right]+\left(1-t_{L i}\right) w_{i}=p_{2} C_{W 2} \text {, if } \epsilon=W \\
S_{i}\left[1+\left(1-t_{k}\right) r\right]=p_{2} C_{R 2} \text {, if } \epsilon=R,
\end{gathered}
$$

Where, the proportional tax on labor income is $t_{L i}$, and the capital income of residents and foreigners (from domestic sources only) is taxed at a flat rate $t_{k} ; C_{t i}$ represents period- $t$ consumption spending, $S_{i}$ denotes period-1 domestic saving of individual I, and $\mathbf{E}_{\epsilon}$ denotes the expectation operator for the distribution function of the non-working shock $\epsilon ; \quad ; I=S$, L..

\section{III.6 Capital Flows}


Recall that the welfare-state fiscal prospects depend on two factors, in order to mitigate adverse macroeconomic impact of ageing. The first is the potential for capital deepening. The second is increased immigration. Domestic capital deepening depends in and out capital flows.

As usual, capital flows are driven by net-of-tax rates of return. Capital does flow internationally, but at some cost $\delta_{k}>0$ per unit. The net return on investing into domestic capital is $1+r\left(1-t_{k}\right)$ for investors, where $r$ is the domestic interest rate. A domestic individual who invests abroad can thus gain only $1+\left(1-t_{K}^{*}\right) r^{*}-\delta_{k}$, where $r^{*}$ is the world interest rate and $t_{K}^{*}$ is the tax rate, levied abroad under a source-based taxation. In a small, open economy context, the two (exogenous) variables $t_{K}^{*}$ and $r^{*}$ play an equivalent role, where the only relevant variable is $R^{*}=$ $\left(1-t_{K}^{*}\right) r^{*}$, which is the net of tax international interest rate. We assume that the cost of capital flows applies symmetrically to foreign investors, i.e. their return on investment in the domestic country is given by $1+\left(1-t_{K}\right) r-\delta_{k}$, where investing abroad yields a return $R^{*}$.

The small open economy exports capital in case:

$$
\left(1-t_{K}\right) r=R^{*}-\delta_{k} .
$$

This means that $\left(1-t_{K}\right) r-\delta_{k}<R^{*}$, and therefore foreigners do not invest in the domestic economy.

Similarly, the small open economy imports capital in case:

$$
\left(1-t_{K}\right) r-\delta_{k}=R^{*}
$$


This means that $\left(1-t_{K}\right) r>R^{*}-\delta_{k}$, and therefore the residents of the small open economy do not wish to invest abroad.

\section{III.7 Current Account}

First-period current account surplus is given by:

$$
(1-\lambda)\left(\bar{x}_{u}+p_{1} \bar{y}_{u}\right)+(\lambda)\left(\bar{x}_{s}+p_{1} \bar{y}_{s}\right)-(1-\lambda)\left(c_{x u 1}+\right.
$$$$
\left.\left.p_{1} c_{y u 1}\right)\right)+(\lambda)\left(c_{x s 1}+p_{1} c_{y s 1}\right)+p_{k}\left(K_{x}+K_{y}\right)=\left[(1-\lambda) S_{u}+(\lambda) S_{s}\right]-
$$

$$
p_{k}\left(K_{x}+K_{y}\right)
$$


Note that when the country exports capital (that is, $(1-\lambda) S_{u}+(\lambda) S_{s}>p_{k}\left(K_{x}+K_{y}\right)$ ), then it incurrs the cost of $\delta_{k}$ on its capital exports. Conversely, when foreigners invest in the domestic economy (that is, $(1-\lambda) S_{u}+(\lambda) S_{s}<p_{k}\left(K_{x}+K_{y}\right)$ ), then the country pays foreiners only $1+\left(1-t_{k}\right) r$, because they are taxed on their income originating in the domestic economy; foreigners bears the friction cost $\delta_{k}$ in this case.

Second period resource constraint is given by:

$$
\begin{aligned}
& (1-\lambda)\left(c_{x u 2}+p_{2} c_{y u 2}\right)+(\lambda)\left(c_{x s 2}+p_{2} c_{y s 2}\right)+m_{H}\left(p c_{x m s 2}+c_{y m s 2}\right) \\
& +m_{L}\left(\left(p c_{x m L 2}+c_{y m L 2)}+d c_{d e p}+\left(1+m_{L}+m_{H}+d\right) B\right.\right. \\
& =F_{x}\left(K_{x}, L_{x}\right)+p_{2} F_{y}\left(K_{y}, L_{y}\right)+\left[(1-\lambda) S_{u}+() S_{s}-p_{k}\left(K_{x}+K_{y}\right)\right] I_{C F}
\end{aligned}
$$

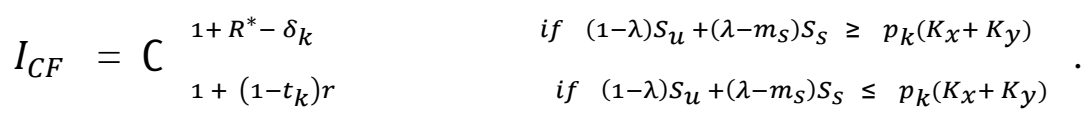

\section{III.8 Policy Instruments}

Finally, consider the government, which is active in a balanced-budget way only in the second period. Its budget constraint is:

$$
\begin{aligned}
& \left(1+m_{H}+m_{L}+d\right) B=t_{L L}\left(w_{L}\left((1-\lambda) \emptyset+m_{L}\right)+t_{L S} w_{S}\left(\lambda \emptyset+m_{S}\right)+\right. \\
& t_{k} r p_{k}\left(K_{x}+K_{y}\right) .
\end{aligned}
$$


Note that the government taxes capital income of both domestic residents and foreigners which originates in the domestic economy, $r p_{k}\left(K_{x}+K_{y}\right)$. This means that when saving of domestic residents exceeds domestic investment, $p_{k}\left(K_{x}+K_{y}\right)$, with the excess invested abroad, then this excess is not taxed at home. Conversely, when savings of domestic residents fall short of domestic investment, $p_{k}\left(K_{x}+K_{y}\right)$, with the shortage financed by foreigners, then this shortage is taxed by the domestic government.

The available policy instruments are the number of high-skilled migrants, $m_{H}$, the number of low -skilled migrants, , $m_{L}$, the labor income tax rates, $t_{L S}$ and $t_{L L}$ (proportional wage tax rates on high-skill and low-skill, respectively), the capital income tax rate, $t_{k}$, and the scale of the social benefit, $B$. Labor income tax is progressive (measured by the difference in the average rate differential $\left.t_{L S}-t_{L L}>0\right)$, whereas capital income tax $\left(t_{k}\right)$ is proportional.

Note also that the government taxes capital income of both domestic residents and foreigners which originates in the domestic economy, $r p_{k}\left(K_{x}+K_{y}\right)$. This means that when saving of domestic residents exceeds domestic investment, $p_{k}\left(K_{x}+K_{y}\right)$, with the excess invested abroad, then this excess is not taxed at home. Conversely, when savings of domestic residents fall short of domestic investment, $p_{k}\left(K_{x}+K_{y}\right)$, with the shortage financed by foreigners, then this shortage is taxed by the domestic government.

We abstract from a tax on the initial endowments because these are in fixed supply at the beginning of the first period, and a tax on them is not distortive; it will tend to be extremely high. Furthermore, when the low-skill form the majority, they will tax them at a rate of $100 \%$. For a similar reason, 
we abstract also from a tax on consumption (VAT) because it is equivalent to a tax on wages (which are taxed directly in our model), and a tax on the initial endowments (see, for instance, Frenkel, Razin and Sadka (1991)).

\section{Model's Predictions}

To capture the effect of ageing (that is, a rising share of dependents with the $\emptyset$-parameter) on social insurance, the composition of taxes, and the skill gap of immigration, resort to numerical simulation.

\section{IV.1 Majority Determined Policy}

In the following Figures we compare the high skilled regime policies with the low-skilled regime policies, through varying the retirement-likelihood parameter, $\emptyset$.

Figure 1: Capital income tax: high skilled majority vs. low-skilled majority 




Note: For $\emptyset$-parameter values falling short of 0.2 the economy imports capital. For $\emptyset$-parameter values exceeding 0.35 the economy exports capital. For $\emptyset$-parameter values in between 0.2 and 0.35 the economy is in financial autarky. For the model's parameter values, see Appendix.

Figure 1 demonstrates that,

1. The capital tax rate set by the high-skilled majority is higher than the rate set by the lowskilled majority if the country is capital exporter. The capital tax rate is set equal to zero set by the high-skilled majority if the country is capital exporter.

2. Increasing the $\varnothing$-parameter lowers the capital tax rate set by the high-skilled majority if the country is capital exporter. Increasing the $\emptyset$-parameter lowers the rate of tax on capital by the low-skilled majority, regardless of whether the country exports or imports capital. 
Figure 2: low-wage tax rate: high skilled majority vs. low-skilled majority

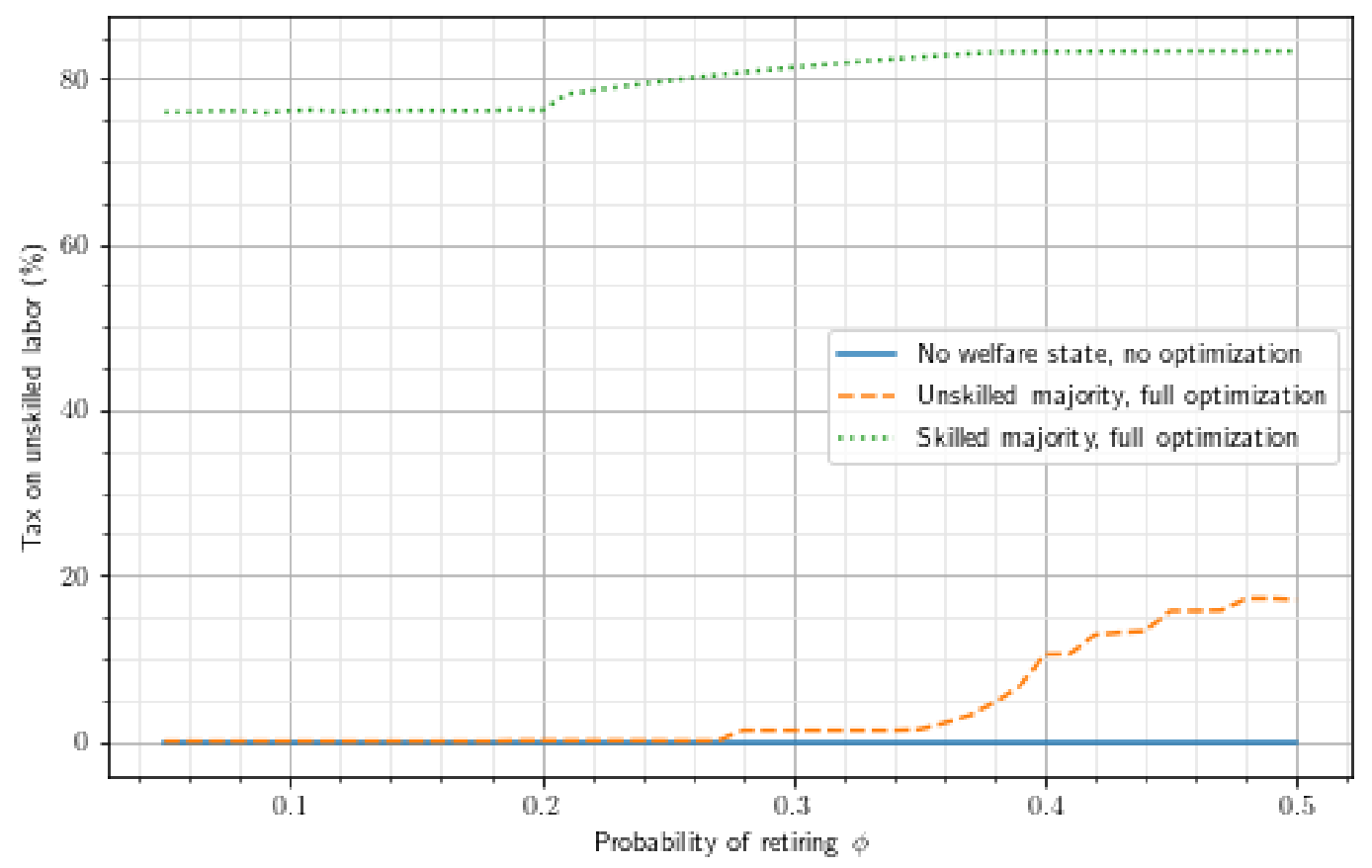

Note: For $\emptyset$-parameter values falling short of 0.2 the economy imports capital. For $\emptyset$-parameter values exceeding 0.35 the economy exports capital. For $\emptyset$-parameter values in between 0.2 and 0.35 the economy is in financial autarky. For the model's parameter values, see Appendix.

Figure 2 demonstrates that,

1. The low-wage tax rate set by the high-skilled majority is higher than the rate set by the low-skilled majority. 
2. Increasing the $\emptyset$-parameter raises the low-wage tax rate by both the high-skilled and low-skilled regimes.

Figure 3: High-wage tax rate: high skilled majority vs. low-skilled majority

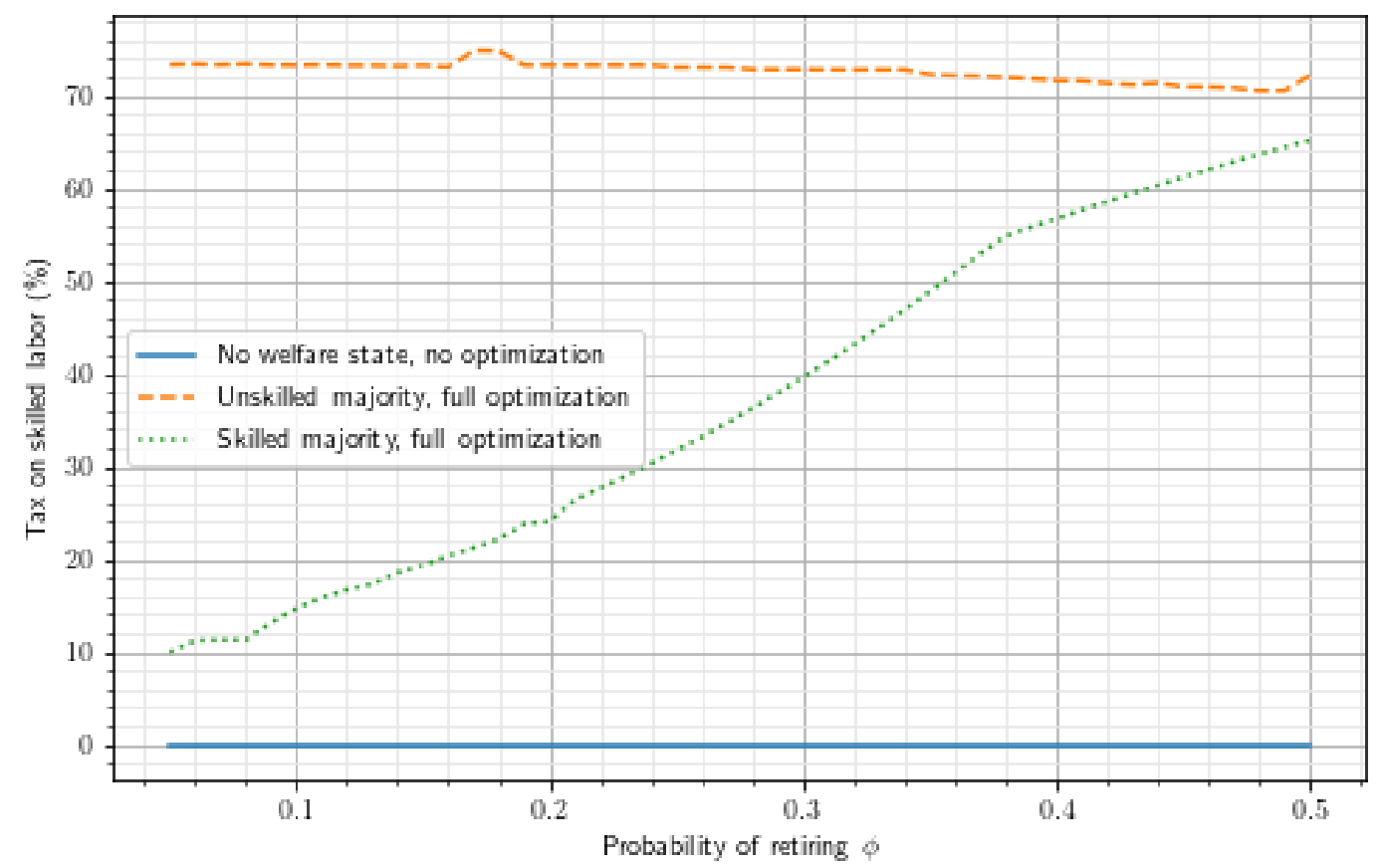

Note: For $\emptyset$-parameter values falling short of 0.2 the economy imports capital. For $\emptyset$-parameter values exceeding 0.35 the economy exports capital. For $\emptyset$-parameter values in between 0.2 and 0.35 the economy is in financial autarky. For the model's parameter values, see Appendix. 
Figures 3 demonstrate that,

1. The high-wage tax rate set by the high-skilled majority is lower than the rate set by the low-skilled majority.

2. Increasing the $\emptyset$-parameter raises the high-wage tax rate by the high-skilled but lowers the rate set by low-skilled regime.

Figure 4: Provision of social benefits: high-skilled majority and low-skilled majority

3. The high-wage tax rate set by the high-skilled majority is lower than the rate set by the low-skilled majority.

4. Increasing the $\varnothing$-parameter raises the high-wage tax rate by the high-skilled but lowers the rate set by low-skilled regime. 


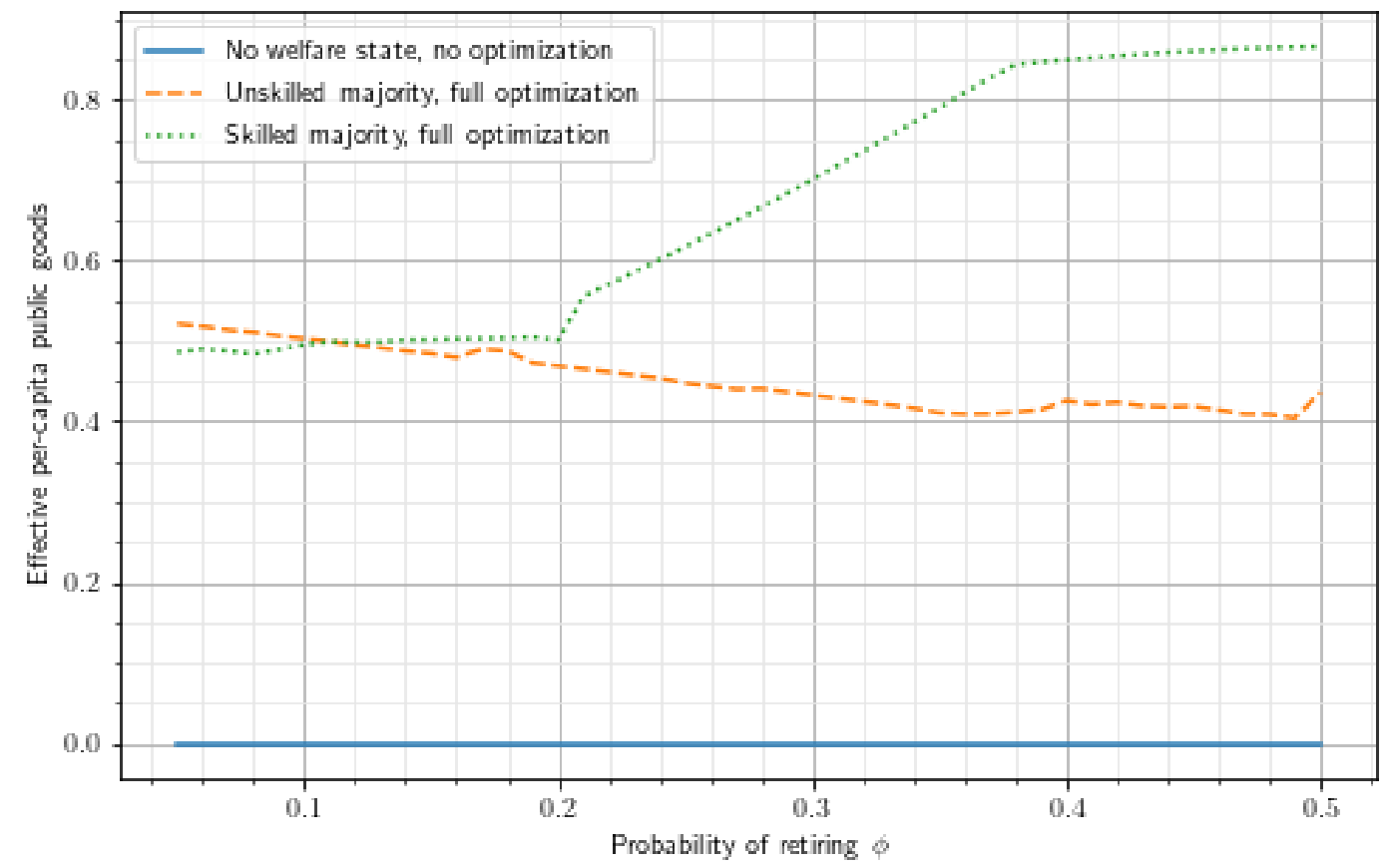

Note: For $\emptyset$-parameter values falling short of 0.2 the economy imports capital. For $\emptyset$-parameter values exceeding 0.35 the economy exports capital. For $\emptyset$-parameter values in between 0.2 and 0.35 the economy is in financial autarky. For the model's parameter values, see Appendix.

Figure 4 shows that,

1. The high-skilled regime provides greater social benefits than the low-skilled regime (except for very low values of the $\emptyset$-parameter where the provision is similar).

2. Increasing the $\varnothing$-parameter raises social-benefit provision in the high-skilled regime but lowers the provision in the low-skilled regime. 
Figure 5: low-skilled-migration quota: high-skilled majority and low-skilled majority

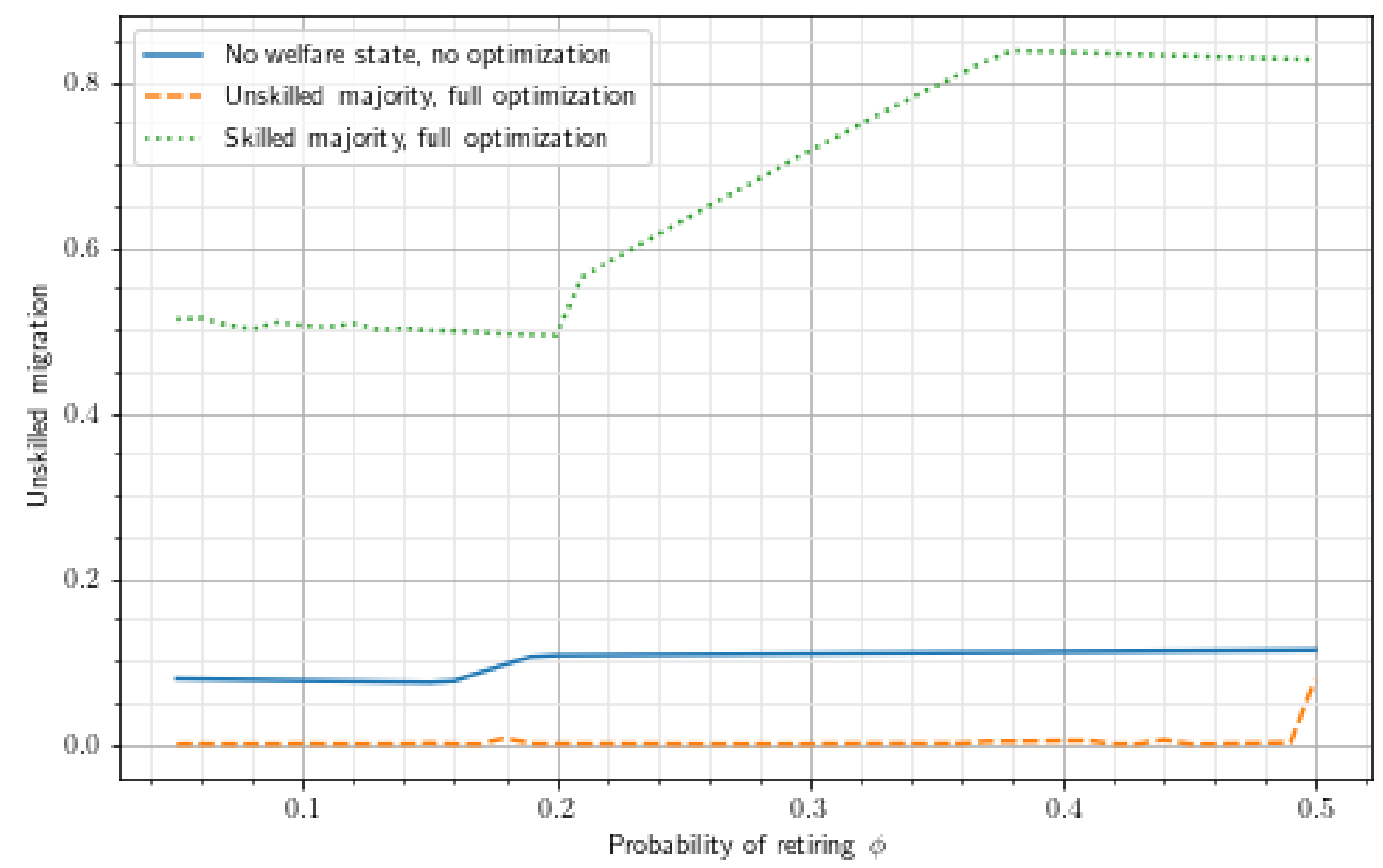

Note: For $\emptyset$-parameter values falling short of 0.2 the economy imports capital. For $\emptyset$-parameter values exceeding 0.35 the economy exports capital. For $\emptyset$-parameter values in between 0.2 and 0.35 the economy is in financial autarky. For the model’s parameter values, see Appendix.

Figure 2 shows that, 
1. The high-skilled regime sets positive (and high) the migration quota to low-skilled migrants, whereas the low-skilled regime sets the quota equal to zero.

2. Increasing the $\emptyset$-parameter does not change the low-skilled migration quota if the highskilled form the majority if the country is capital importer or exporter. Increasing the $\varnothing$ parameter raises the low-skilled migration quota, when the high-skilled form the majority, if economy is in financial autarky.

Figure 6: high-skilled-migration quota: high skilled majority and low-skilled majority




Note: For $\emptyset$-parameter values falling short of 0.2 the economy imports capital. For $\varnothing$-parameter values exceeding 0.35 the economy exports capital. For $\emptyset$-parameter values in between 0.2 and 0.35 the economy is in financial autarky. For the model's parameter values, see Appendix.

Figures 6 shows that,

1. The quota for high-skilled migration set by the high-skilled regime is zero and the quota set by the low-skilled regime is positive if the country imports capital; If the country exports capital, the quota set by the high-skilled regime exceeds the quota set by the lowskilled regime.

2. Increasing the $\emptyset$-parameter lowers the high-skilled migration quota set by low-skilled regime; increasing the $\emptyset$-parameter lowers the high-skilled migration quota set by the high-skilled regime once the country becomes capital exporter.

\section{IV.2 Free migration vs. Restricted Migration}

In the following Figures we compare the free-migration regime with the restrictedmigration regime, through varying the retirement-likelihood parameter, $\varnothing$.

Figure 7: provision of social benefit: Free Migration vs. Restricted migration 
(High skilled form the Majority)



Note: For $\emptyset$-parameter values falling short of 0.2 the economy imports capital. For $\emptyset$-parameter values exceeding 0.35 the economy exports capital. For $\emptyset$-parameter values in between 0.2 and 0.35 the economy is in financial autarky. For the model's parameter values, see Appendix.

Figure 7 shows that,

1. The provision of the social benefit exceeds the provision under restricted migration.

2. Under free migration, increasing the $\emptyset$-parameter raises the provision of the social benefit under both free- and restricted-migration.

Figure 7: provision of social benefit: Free Migration vs. Restricted migration 


\section{(Low skilled form the Majority)}

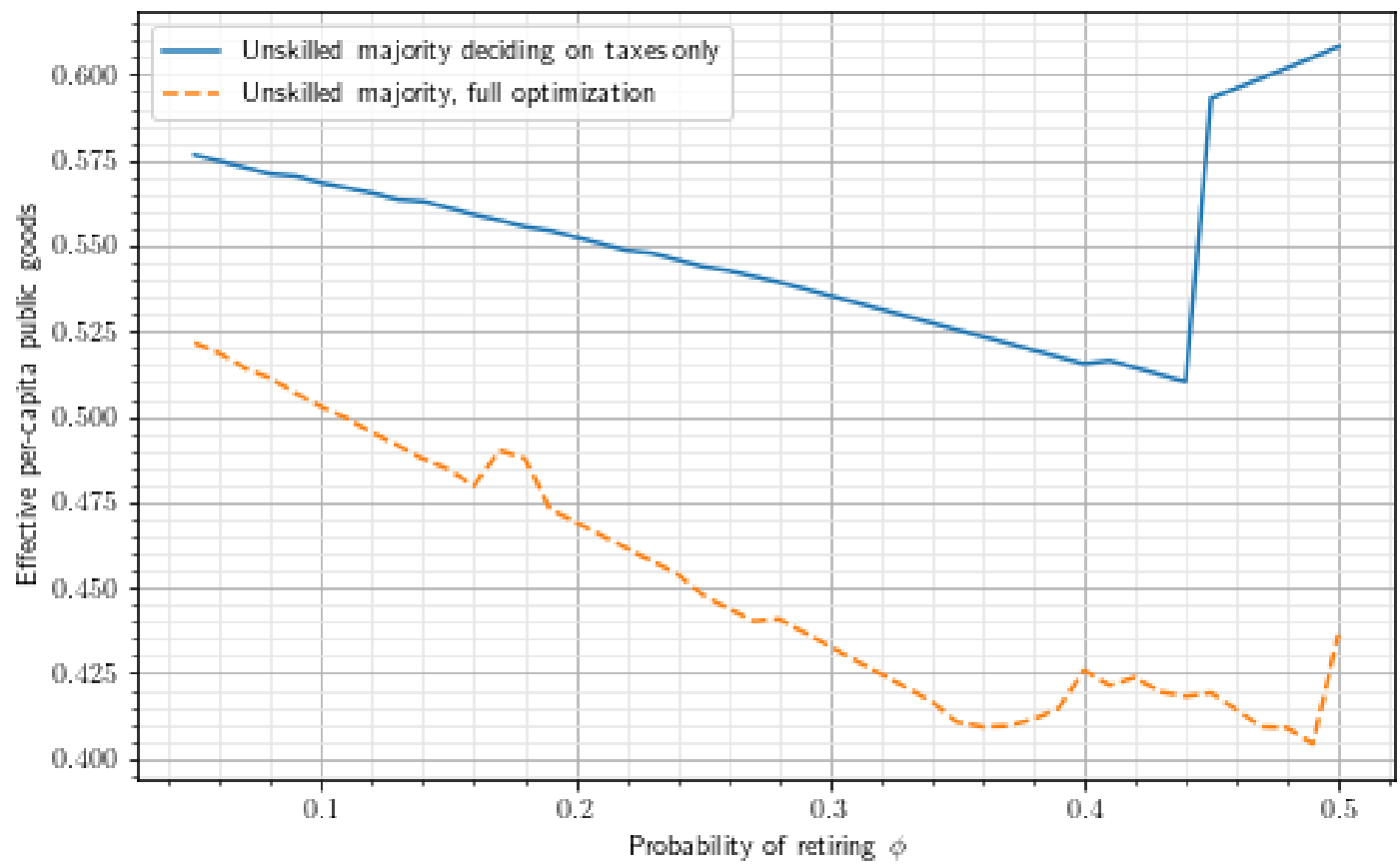

Note: For $\emptyset$-parameter values falling short of 0.2 the economy imports capital. For $\emptyset$-parameter values exceeding 0.35 the economy exports capital. For $\emptyset$-parameter values in between 0.2 and 0.35 the economy is in financial autarky. For the model's parameter values, see Appendix.

1. The provision of the social benefit, under free migration, exceeds the provision under restricted migration.

2. Increasing the $\emptyset$-parameter raises the provision of the social benefit under both freeand restricted-migration as long as the economy imports capital. 
Figure 8: Share of high-skilled immigration in total immigration Free Migration vs.

\section{Restricted migration}

\section{(High skilled form the majority, Low skilled form the Majority)}

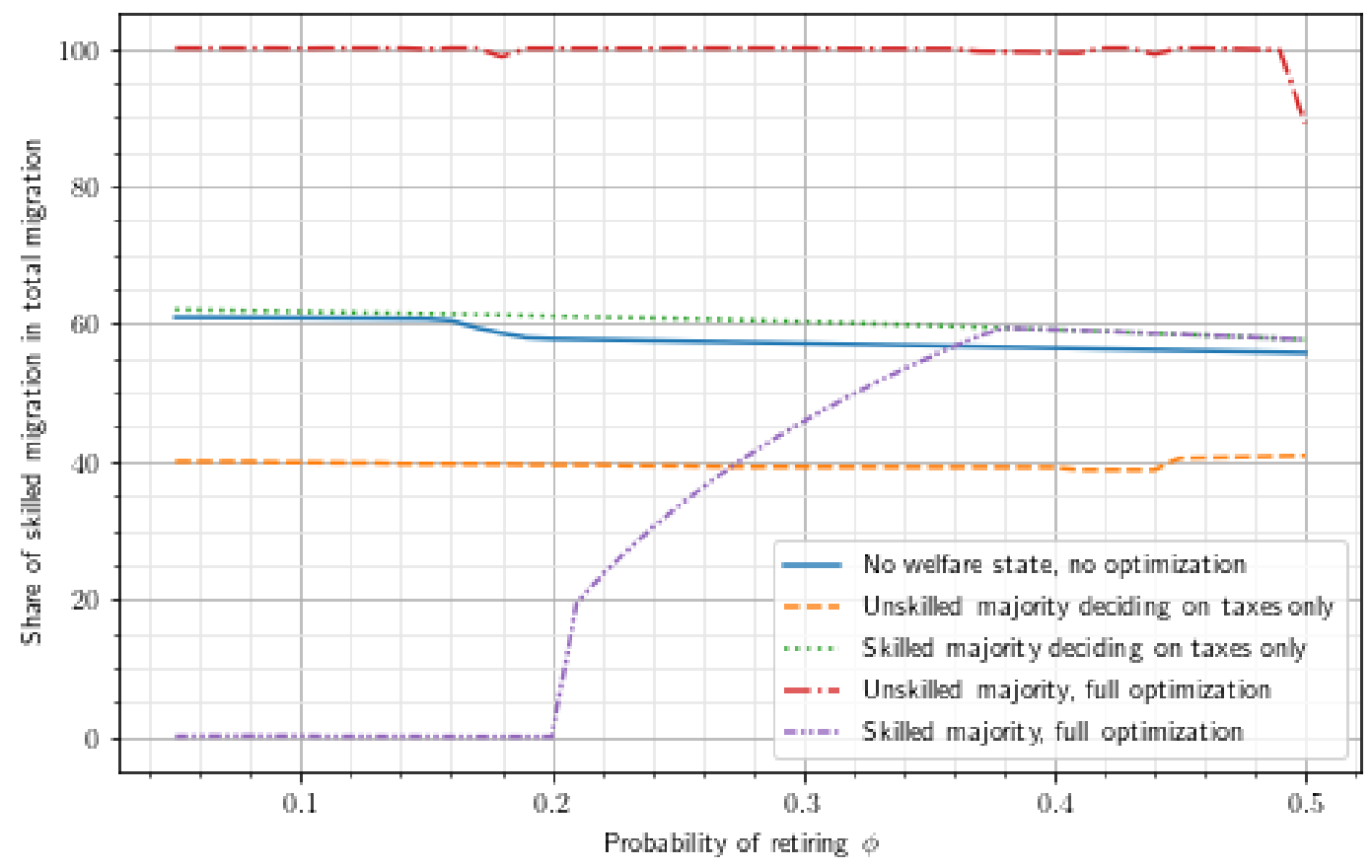

Note: For $\emptyset$-parameter values falling short of 0.2 the economy imports capital. For $\emptyset$-parameter values exceeding 0.35 the economy exports capital. For $\emptyset$-parameter values in between 0.2 and 0.35 the economy is in financial autarky. For the model’s parameter values, see Appendix. 
Figures 8 shows that,

1. If the low skilled form the majority which control the welfare-state policy, free-migration share of high- skilled falls short of the migration-restricting regime.

When the high skilled form the majority which control the welfare-state policy, freemigration share of high- skilled exceeds (falls short) of the migration- restricting regime for capital-import (export)country .

\section{Summary conclusion}

The paper compares policy regimes, dealing with migration and redistribution Migration quotas of low skilled and high skilled, provision of social benefits, labor income taxation, capital income taxation, - are all endogenously determined in a general-equilibrium optimizing framework. Main driving force is ageing of the population. The analysis involves three-way comparisons: freemigration regime differentiated from restricted-migration regime, welfare-state regime 
distinguished from free-market regime, and low-income-majority regime assessed against highincome-majority regime.

Main patterns, distilled from the analysis, are as follows.

\section{Welfare-state generosity and migration}

The provision of social benefits by the welfare state decline when the country switches from freeto restricted-migration. In a capital exporting country, which have high demand for high-skill labor, the share of high skilled immigrants in total number of immigrants rises when the country switches from free- to restricted-migration. Social provisions rise with ageing if the high skilled form the majority, and fall if the low skilled form the majority.

The share hare of skilled migration in total migration rises with ageing across if the high skilled form the majority. The share is set equal to one if the low skilled form the majority. Migration of low skilled rises with ageing if the high skilled form the majority. Migration is wholly prevented if the low skilled form the majority. Migration of high skilled rises with ageing across if the high skilled form the majority and declines if the low skilled form the majority.

\section{Taxation shifts from capital to labor}

First, Capital income tax rate declines with ageing across all policy regimes. Second, the tax rate on low wage rises with ageing across all policy regimes. The tax rate on high wage rises with ageing across all policy regimes ${ }^{18}$.

\footnotetext{
${ }^{18}$ Except if the low skilled form the majority where the rate is high for all demographics, which does not show upward trend with ageing)
} 


\section{Appendix: Simulation model and Parameter values}

To simplify the model in the text, the simulation model has a layered production structure with three inputs, two intermediary goods and one final good in each period. This is without much loss of generality, but simplifies the analysis. The final good in each period serves this purpose.

The final good is produced by a Cobb-Douglas production function. Individuals start with an endowment $\theta_{i}$ of the final good, $\mathrm{I}=1,2$. The capital good is produced one-to one from the final good, thus reducing the need to track another production function that is not at the core of the analysis.

Preferences are specified as

$$
u\left(c_{i, t}, b\right)=\frac{c_{i, t}^{1-\sigma}-1}{1-\sigma}+d_{g} \frac{(b)^{1-\gamma_{g}}-1}{1-\gamma_{g}}
$$

Provision of social benefit $b$ is:

$$
b=\frac{B}{\left(\sum_{i} \lambda_{i}+\sum_{m} m_{m}\right)^{\eta_{b}}} .
$$

$B$ is total government spending on public goods, and $\eta_{b} \geq 0$ measures to what extent there are congestion externalities in its provision. In particular, for $\eta_{b}=0$, the public good would be a pure public good, and for $\eta_{b}=1$, only per-person spending on it would be relevant. By setting the value $\eta_{b} \in$

\begin{tabular}{|c|c|c|}
\hline Parameter & Value & Description \\
\hline$\sigma$ & 1.0 & $\begin{array}{l}\text { Elasticity of intertemporal } \\
\text { substitution }\end{array}$ \\
\hline$\gamma_{g}$ & 1.3 & CES parameter public goods \\
\hline$d_{g}$ & 0.5 & Weight public good \\
\hline$\beta$ & 0.5987369392383787 & Discount factor \\
\hline
\end{tabular}
$(0,1)$, we allow for some returns to scale in public goods provision. 


\begin{tabular}{|c|c|c|}
\hline $\bar{b}$ & 0.05 & $\begin{array}{l}\text { Subsistence level of public } \\
\text { goods }\end{array}$ \\
\hline$\delta_{k}$ & 1.0 & Depreciation rate \\
\hline$\omega_{h}$ & 0.0 & $\begin{array}{l}\text { Skilled agents' unskilled } \\
\text { endowment }\end{array}$ \\
\hline$t_{k}^{*}$ & 0.2 & Foreign capital tax rate \\
\hline$\eta_{b}$ & 0.9 & $\begin{array}{l}\text { Congestion in public goods } \\
\text { use }\end{array}$ \\
\hline$n_{u}$ & 1.0 & Labor endowment unskilled \\
\hline$n_{h}$ & 1.0 & Labor endowment skilled \\
\hline$n_{u, m}$ & 1.0 & $\begin{array}{l}\text { Labor endowment unskilled } \\
\text { migrants }\end{array}$ \\
\hline$n_{h, m}$ & 1.0 & $\begin{array}{l}\text { Labor endowment skilled } \\
\text { migrants }\end{array}$ \\
\hline$p_{w}^{*}$ & 1.5 & $\begin{array}{l}\text { Relative price of goods on the } \\
\text { world market }\end{array}$ \\
\hline$P_{w}$ & 1.0 & Price level abroad \\
\hline$A_{w}$ & 1.0 & MFP final goods abroad \\
\hline$\alpha_{x}^{w}$ & 0.5 & World market share of $x$ \\
\hline$r^{*}$ & 3.321942375150668 & Interest rate abroad \\
\hline$\xi$ & 0.0 & Default risk dependents \\
\hline$\mu_{u}$ & 0.0 & $\begin{array}{l}\text { Cost of curbing unskilled } \\
\text { migration }\end{array}$ \\
\hline$\mu_{h}$ & 0.0 & $\begin{array}{l}\text { Cost of curbing skilled } \\
\text { migration }\end{array}$ \\
\hline
\end{tabular}




$\begin{array}{lll}\mu_{h u} & 0.0 & \text { Cost of sorting migrants } \\ \Delta_{y} & 0.01 & \text { Trade wedge } \\ \Delta_{k} & 0.01 & \text { Capital wedge } \\ \gamma & -0.30000000000000004 & \text { Exponent on public good } \\ d & -1.6666666666666665 & \text { Modified weight }\end{array}$

Parameters relating to domestic agents

\begin{tabular}{|c|c|c|c|}
\hline Parameter & Unskilled & Skilled & Description \\
\hline$\lambda_{i}$ & 0.5 & 0.5 & Initial population \\
\hline$\theta_{i}$ & 0.1 & 1.0 & $\begin{array}{l}\text { Elasticity of } \\
\text { immigration }\end{array}$ \\
\hline$\phi_{i}$ & 0.05 & 0.05 & Probability of retiring \\
\hline${ }_{-}^{-}{ }^{\wedge} U i *$ & -10.0 & -9.0 & $\begin{array}{l}\text { Reference utility if } \\
\text { migrating abroad }\end{array}$ \\
\hline$z_{i}^{*}$ & 0.5 & 0.5 & $\begin{array}{l}\text { Elasticity of } \\
\text { emigration }\end{array}$ \\
\hline$Z_{i}$ & 0.3 & 0.3 & $\begin{array}{l}\text { Scaling factor } \\
\text { emigration }\end{array}$ \\
\hline Parameters & ing to $p$ & nmi६ & \\
\hline Parameter & Unskilled & Skilled & Description \\
\hline$Z_{m}$ & 1.0 & 1.0 & $\begin{array}{l}\text { Scaling factor } \\
\text { immigration }\end{array}$ \\
\hline
\end{tabular}



$Z_{m}$
0.5
0.5
Elasticity of
immigration
$U_{m}^{*} \quad-2.255$
$-2.145$
Reference utility of
immigrants

Parameters relating to production structure

\begin{tabular}{|c|c|c|c|c|c|}
\hline \multirow[b]{2}{*}{$g=$} & \multicolumn{3}{|c|}{ Factor shares } & \multicolumn{2}{|c|}{ Other parameters } \\
\hline & $\begin{array}{l}\text { Unskilled } \\
\text { labor }\end{array}$ & Skilled labour & Capital & $\operatorname{MFP}\left(A_{g}\right)$ & $\begin{array}{l}\text { Demand } \\
\text { share }\left(\alpha_{g}\right)\end{array}$ \\
\hline$x$ & 0.3 & 0.4 & 0.3 & 9.0 & 0.5 \\
\hline$y$ & 0.33 & 0.33 & 0.34 & 9.0 & 0.5 \\
\hline
\end{tabular}

\section{Other parameters}

Note: Aan additional layer of production is inserted: Unskilled labor is transformed into unskilled labor services at a rate of 1:1, whereas skilled labor is transformed into skilled labor services at a rate 1:1.5. This ensures that the skilled wage is higher than the unskilled wage. In effect, this is similar to changing $n_{h}$ to 1.5 , but reporting $w_{h} n_{h}$ as the effective wage.

\section{References}

Abramizky, Ran, and Leah Boustan (2017) “Immigration in American Economic History,” Journal of Economic Literature, 55 (2017) 1311-45.

Bentley, A. 1908. The Process of Government, Chicago: University of Chicago Press.

Blank, R. M. (1988). The effect of welfare and wage levels on the location decisions of female-headed households. Journal of Urban Economics, 24, 186. 
Boeri, Tito, (2008), “brain gain: a European approach,” Cesifo Forum 3, 30-34.

Boeri, Tito, (2010), “Immigration to the land ofredistribution,”Economica, 77, 651-687.

Boeri, Tito, Gordon H. Hanson, and Barry McCormick (eds) (2002), Immigration Policy and the Welfare System, A Report for the Fondazione Rodolfo Debenedetti, Oxford University Press.

Borjas, George J. (1999), “The Economic Analysis of Immigration,” in Orly Ashenfelter and David Card (eds.), ㅂandbook of Labor_Economics, Volume 3, Chapter 28, Elsevier.

Borjas, G. J. (1999). Heaven's door: immigration policy and the American economy. Princeton: Princeton University Press.

Borjas, G J (2003), “The Labor Demand Curve is Downward Sloping: Reexamining the Impact of Immigration on the Labor Market,” The Quarterly Journal of Economics 118(4): 1335-1374. Brochmann, Grete, Anniken Hegelund, Karin Borevi, Heidi Vad Johnsson, and Klaus Petersen, (2012), Immigration Policy and the Scandinavian Welfare State 1945-2010, Palgrave MacMillan.

Card, D (2001), “Immigrant Inflows, Native Outflows, and the Local Labor Market Impacts of Higher Immigration,” Journal of Labor Economics 19(1): 22-64.

Card, D (2005), “Is the New Immigration Really So Bad?”, The Economic Journal 115(507).

Cremer Helmuth and Catarina Goulão (2014), “ Migration and Social Insurance,” Louvain Economic Review Volume 80, Issue 1, pp. 5-29. 
Disney, Richard (2007) “ Population ageing and the size of the welfare state: Is there a puzzle to explain?,” European Journal of Political Economy, Volume 23, Issue 2, June 2007, Pages 576577.

Dustmann, Christian , and Tomasso Frattini, (2014), “The Fiscal Effects of Immigration to the UK,” Economic Journal, 124(580).

Dustmann, C, U Schonberg, and J Stuhler (2017), “Labor Supply Shocks, Native Wages, and the Adjustment of Local Employment,” The Quarterly Journal of Economics 132(1): 435-483.

Facchini, Giovanni, Assaf Razin, and Gerald Willman, (2004), "Welfare Leakage and Immigration Policy,” CESifo Economic Studies, Vol. 50, 4/2004.

Foged, M, and G Peri (2016), “Immigrants' Effect on Native Workers: New Analysis on Longitudinal Data," American Economic Journal: Applied Economics 8(2): 1-34.

Freeman, Gary P., (1986), “Migration and the Political Economy of the Welfare State,” Annals of the American Academy of Science AAPS 485, May.

Freeman, G. 1995. 'Modes of immigration politics in liberal democratic states'. International Migration Review, 29(4): 881-902.

Freeman, Richard B., "People Flows in Globalization," Journal of Economic Perspectives, June 2006, 20 (2), 145-170.

Frenkel, Jacob, Assaf Razin, and Efraim Sadka (1990), "Basic Concepts of International Taxation”, NBER Working Paper No. 3540. 
Gimpel, J. and Edwards, J. 1999. The Congressional Politics of Immigration Reform, Boston: Allyn \& Bacon.

Goldin, Claudia (1994), “ The Political Economy of Immigration Restriction in the United States, 1890 to 1921,” in Claudia Goldin and Gary D. Libecap (editors) The Regulated Economy: A Historical Approach to Political Economy, NBER and University of Chicago Press.

Haus, L. 1995. 'Openings in the wall: transnational migrants, labor unions, and US immigration policy'. International Organization, 49(2): 285-313.

Joppke, C. 1999. Immigration and the Nation-State: The United States, Germany, and Great Britain, Oxford: Oxford University Press.

Kapur, Davesh, and John McHale. 2005. Give Us Your Best and Brightest. Washington: Center for Global Development.

Key, V. 1942. Politics, Parties and Pressure Groups, New York: Thomas Y. Crowell.

Khoudour-Castéras, D. (2008). "Welfare state and labor mobility: the impact of Bismarck’s social legislation on German emigration before World War I,” The Journal of Economic History, 68(1), 211243.

Levine, P. B., and Zimmerman, D. J. (1999). An empirical analysis of the welfare magnet debate using the NLSY. Journal of Population Economics, 12(3), 391.

Lindbeck, Assar (1985), “Redistribution policy and the expansion of the public sector,” $\underline{\text { Journal of }}$ Public Economics, Volume 28, Issue 3, December 1985, Pages 309-328.

Lovell, M. C. (1975). The collective allocation of commodities in a democratic society. Public Choice 24, 71-92.

Meltzer, ; Allan and Scott F. Richard, “A Rational Theory of the Size of Government,” Journal of Political Economy 89 (1981): 914-27.

Meyer, J.-B. (2003). “Diasporas: concepts et pratiques.,”In R. Barre, V. Hernandez, J.-B. Meyer, \& D. Vinck (Eds.), Scientific Diasporas. Expertise collégiale, IRD Editions.

Oates, Wallace (1972), Fiscal Federalism, Harcourt Brace and Jovanovitch, New York.

Pritchett,Lant (2006).,"Let Their People Come: Breaking the Gridlock on International Labor Mobility," 
Center for Global Development: Brookings Institution Press, 2006.

Ottaviano, G I, and G Peri (2012), "Rethinking the Effect of Immigration on Wages,” Journal of the

European Economic Association 10(1): 152-197.

Razin, Assaf (2018), "Israel Immigration Story: Winners and Losers," Israel Economic Review Vol. 15, No. 1

(2018), 1-33.

Razin, Assaf, Efraim Sadka and Phillips Swagel (2002a), "The Aging Population and the Size of the Welfare State," Journal of Political Econ omy, 110, pp. 900-918.

Razin, A., E. Sadka, and P. Swagel (2002b). Tax burden and migration: A political economy theory and evidence. Journal of Public Economics 85, 167-190.

Razin, Assaf and Jackline Wahba, (2015), “Welfare Magnet Hypothesis, Fiscal Burden, and Immigration Skill Selectivity,” Scandinavian Journal of Economics, Volume117, Issue 2, April 2015, Pages 369-402.

Razin, Assaf, Efraim Sadka, and Alexander Schwemmer, (2019) "Welfare State vs. Market Forces in a Globalization Era” , CEPR D DP13937.

Razin, Assaf and Efraim Sadka (1991), "International Tax Competition and Coordination", Economic Letters.

Razin, Assaf, Efraim Sadka, and Ben Suwankiri, (2011), Migration and the Welfare State: PoliticalEconomy Policy Formation, MIT Press.

Roberts, Kevis, (1977) “Voting over Income Tax Schedules,” Journal of Public Economics 8 (1977): 329-40.

Scheve, K. and Slaughter, M. 2001. 'Labor market competition and individual preferences over immigration policy'. The Review of Economics and Statistics, 83(1): 133-45.

Truman, D. 1951. The Governmental Process, New York: Knopf.

Watts, J. 2001. Immigration Policy and the Challenge of Globalization: Unions and Employers in Unlikely Alliance, Ithaca: Cornell University Press.

Zaiceva, Anzelika, and Klaus F. Zimmermann, (2016), "Migration and the Demographic Shift," 
In John Piggott, Alan Woodland (eds.), Handbook of the Economics of Population Aging, Volume 1, Chapter 3, Pages 119-169. 
Gramlich, E. M., and Laren, D. S. (1984). Migration and income redistribution responsibilities. The Journal of Human Resources, 19(4), 489.

Khoudour-Castéras, D. (2008). Welfare state and labor mobility: the impact of Bismarcks social legislation on German emigration before World War I. The Journal of Economic History, 68(1), 211-243.

Levine, P. B., and Zimmerman, D. J. (1999). An empirical analysis of the welfare magnet debate using the NLSY. Journal of Population Economics, 12(3), 391.

Meyer, J.-B. (2003). Diasporas: concepts et pratiques. In R. Barre, V. Hernandez, J.-B. Meyer, \& D. Vinck (Eds.), Diasporas scientifiques/Scientific Diasporas. Expertise collégiale. Expertise collégiale, IRD Editions. Southwick, L. Jr. (1981). Public welfare programs and recipient migration. Growth and Change, 12(4), 22. 